political processes, including electoral processes, promoting inclusive dialogue and reconciliation, and developing conflict-management capacity at national and subnational levels."

Peace building as a major concept in conflict resolution and management has been defined as, a means of preventing the outbreak, reoccurrence or continuation of armed conflicts and as well as emergences in a wide range of political, developmental, humanitarian and human right mechanism The process of peace building therefore compasses all the stages of conflict, from the preconflict to the post conflict phase, with aim of laying the basis for sustainable peace in conflict torn society ( Karame, 2004).

Women's Participation: As defined by Security Council Resolution 1325 (2000) this refers to the "role of women in the prevention and resolution of conflicts and in peace-building, and...their equal participation and full involvement in all efforts for the maintenance and promotion of peace and security, and the need to increase their role in decision-making with regard to conflict prevention and resolution."

Gender. UN Women, define Gender as the social construction of men's and women's roles in a given culture or location. Gender roles are distinguished from sex roles, which are biologically determined. The concept gender also includes the expectations held about characteristics, aptitudes and likely behaviors of both women and men. These roles and aptitudes can change over time and they vary between cultures. The concept gender is important when applied to peace building and conflict resolution because it reveals how women's subordination despites actions and efforts are socially constructed.

\section{Gender equality}

Gender equality is when there is no discrimination on the grounds of a person's sex in the allocation of resources, benefits or in the access to services. Gender equality, may be measured in terms of whether there is equal valuing by society of both the similarities and differences between women and men as they carry out their roles. Equality will improve on Women's position by giving those rights in resources, and political voice and contribution to sustainable development.
Gender Mainstreaming: As defined by the UN Economic and Social Council (ECOSOC) this refers to "the process of assessing the implications for women and men of any planned action, including legislation, policies or programs, in all areas and at all levels. It is a strategy for making women's as well as men's concerns and experiences an integral dimension of the design, implementation, monitoring and evaluation of policies and programs in all spheres, so that women and men benefit equally, and inequality is not perpetuated.

\section{0-INTRODUCTION}

Women in West Africa just like others in the rest of the world have played significant roles in situations relating to peace and war for centuries. Their participation has been as citizens who are recognized under the custom and law as being a legal member of their sovereign state. Women have always made a unique contribution in the peace-building process. In all areas, whether it's peace-building or any other thing, women's role cannot be ignored and their contribution brings development not only for themselves, but as well as for the entire world. Through peace building, women can bring different issues in front of the world and can make better decisions to solve these issues. They can better understand the issues and can follow the rules to solving the problems and issues. They have acted primarily as traditional peace-makers, as priestesses who confer with gods to determine whether it was right to go to war or not, as praise singers for men during battles as a boost to ensure their victory, or as custodians of culture. In each culture there are stories of women who have played some leadership and other roles as peace envoys or harbingers of peace in their communities. However, as the trend of wars and armed conflicts in West Africa changed, women became the victims of unimaginable forms of violence as a tactic of war that they suffer more than their male counterparts (Ngongo-Mbede, 2003). All nations in Africa have come to realize the gendered effects of conflict and both men and women are heavily involved in the different dimensions of peace building which includes the two broad approaches to peace building like first, peace building that refers to direct work that intentionally focuses on addressing the factors driving or mitigating conflict (Korb, 2011).

When applying the term "peace building" to this work, there is an explicit attempt by those designing and planning a peace building effort to reduce 
structural or direct violence and second, the term peace building can also refer to efforts to coordinate a multi-level, multispectral strategy, including ensuring that there is funding and proper communication and coordination mechanisms between humanitarian assistance, development, governance, security, justice and other sectors that may not use the term "peace building" to describe themselves. The concept is not one to impose on specific sectors (Bryman 2012).

With the unanimous adoption of Resolution 1325 by the United Nations Security Council (UNESCO,2006) in O October 2000, women's role in, and potentials for peace building have gained global, regional and national attention. Consequently, the last six years have been characterized by the identification of key issues on women, peace and security, and the development of interventions to address them. While women in Cameroon like their counterpart all over Africa and the world gets involved in national and international preservation of peace, the question now is what actually is the role of women in the preservation of peace? This is because fundamental concerns about peace and citizenship lies on human rights and when human rights are violated then there are bound to be conflicts for men and women that quickly steal away their peace. This Paper has the following specific objectives: It seeks to:

$>$ Analyze the nature of women's involvement in peace building in Cameroon.

$>$ Examine some of the challenges women face in their effort to preserve peace.

$>$ Discuss the mainstreaming of gender in conflict and peace building interventions, highlighting some best practices.

\subsection{THEORITICAL PERSPECTIVE}

This write up is purely descriptive guided by a number of Feminist Peace and Conflict Theories (FPCT) that helped the writer to understand and assess the complexities that women undergo in the society as they generally participate in the peace building process.

Feminist Peace and Conflict Theory (FPCT) reflects on the need of visibility of women in conflicts and peace concerns and has led to a broader understanding of gender peace and security issues in the society and introduces the interconnectedness of all forms of violence ( domestic, societal, state based and interstate ) to gendered dimension of peace building. According to the Conflict perspective by Collins,
1975; Vogel, 1983; Collier, 1988; Bradley, 1989 as in. (Frances \& Kolma 2005), there is the contention that sexual division of labour is a social vehicle devised by men to ensure themselves privilege and power in their relationships with women. Richardson (1987) as in (Frances \& Kolma 2005), in his Interactionist theory argue that gender inequality persist because of the way men and women and other appropriate roles in society are define. Feminists questioned earlier the gender dynamics of the French Revolution and other revolutions (Mary Wollstonecraft, 1792) and the exclusion of women from the acclaimed new status of citizenship that only lead to the deepening of concerns related to gender inequality.

All the FCPT argued that in the society general, some aspects of female subordination and gender inequality exist which goes a long way to affect human right concerns that affects national peace and citizenship, which could be closely related to issues of peace and conflict management.Emphasizing on patriotism, this argument about women and peace is based on their participation and decision making, similar to the position taken by liberal feminists on the question of women in the army and possible conflict resolution processes and activities.

All the feminist theories discussed have their relevance in this paper following the major high lights that are closely related to the gender differences in roles and consequences of conflict and the peace building process. Since both men and women are affected by the gendered effects of conflicts, both gender should effectively participate in the national and international peace building processes in Cameroon.

\section{ANALYZE OF THE NATURE OF WOMEN'S INVOLVEMENT IN PEACE BUILDING IN CAMEROON.}

This has to do with women natural and other useful qualities as peace builders, their role seen in their necessary actions or activities and what the actually do to contribute to peace building in their country.

\section{Women's Role in the different Phases of Peace building}

Peace is fundamental in many of Cameroon's cultural universe and Women are seen to play a great role in maintaining this peace. Women are the threads that hold together the social fabric of society. In most of the African countries, they are involved in the 
different phases of peace building which is generally seen in their activities (Harermans, 2000) as in McGuinness (2007)

Peace building is an intervention that is designed to prevent the start or resumption of violent conflict by creating a sustainable peace. Peace building activities address the root causes or potential causes of violence, create a societal expectation for peaceful conflict resolution and stabilize society politically and socioeconomically.

There are a number of peace building activities depending on the situation and the agent of peace building. Successful peace building activities create an environment supportive of self-sustaining, durable peace; reconcile opponents; prevent conflict from restarting; integrate civil society; create rule of law mechanisms; and address underlying structural and societal issues. According to some researchers and practitioners peace building is most effective and durable when it relies upon local conceptions of peace and the underlying dynamics which foster or enable conflict (Coning, 2013)

So far as earlier indicated, Cameroon has been and is hit by major crisis/conflicts, including the Bakassi peninsular crisis with Nigeria, the Boko Haram Terrorist attacks from 2015 till now and the Anglophone crisis in the North West and South West Regions of the country. In combating this crisis, women alongside men have played key roles, traditionally, domestically and politically to ensure the establishment of peace especially in their immediate communities and nation.

There are two broad approaches to peace building. First; peace building can refer to direct work that intentionally focuses on addressing the factors driving or mitigating conflict. When applying the term "peace building" to this paper, there is an explicit attempt by those designing and planning a peace building effort to reduce structural or direct violence and second, the term peace building can also refer to efforts to coordinate a multi-level, multisectoral strategy, including ensuring that there is funding and proper communication and coordination mechanisms between humanitarian assistance, development, governance, security, justice and other sectors that may not use the term "peace building" to describe themselves. Rather some scholars use the term peace building is an overarching concept useful for describing a range of interrelated efforts. (Harermans, 2000)

Generally women can be involved in these two approaches as they engage in the three phases like pre-conflict phase that strengthen and promote activities, local women's organizations and can initiatives and promote peace initiates and foster an atmosphere of conviviality in their communities. The formation of network (peace alliances) by women can promote cooperation and trust which will eliminate the causes of conflict (Mpangala, 2004).During armed conflict, women can contribute to peace building by becoming combatants just like men, providing weapons to men, spying and functioning as mail runners and caregivers to children and taking the responsibility Local women's peacekeeping organization can step up their role as negotiators and mediators between the warring parties and encourage dialogue between them and in refugee camp, women have responsibility for avoiding existential hardship. Women ensure the fair distribution of food, allowances for the special needs of women, girl. Prevention of harassment by male refugees. In the post conflict phase of a conflict.

Women particularly play important role during the peace process and also in the re-integration phase. Of particular significance here in that pre-conflict and post-conflict phases above all share marked parallels. The requisite measures are often similar, since peace building and conflict prevention are essential before and after a conflict. Women can play the following roles in this phase. More of Women's significant role here in decision-making functions through their full participation in conflict settlement and peace processes. Women can also act in this phase as negotiators and mediators to encourage dialogue between parties. By highlighting the need of women in the demobilization and reconstruction phase, women's groups and networks can make an important contribution to sustainable peace process especially as they are emotionally better placed to handle decisions regarding compensation for suffering caused by sexual violence predicament of rape victims, women sex slaves returning, perhaps pregnant (Korb, 2011).

Irrespective of the above, Cameroonian women have been more involved in all the processes of conflict prevention and the promotion, consolidation and reconstruction of peace and security. This followed the resolutions and strategies that were adopted in 
Yaounde on the occasion of the national information and sensitization workshop on UN Resolution 1325 on gender, peace and security organized by the Centre for Human Rights and Peace Advocacy.( The advocates for Human rights ,2014)

\section{Women's useful qualities for peace building}

Women by their nature and role have some useful qualities for peace building. According to UNESCO's Women and the Culture of Peace program in all cultures of Cameroon peace is equated with 'freshness, health, well-being, harmony, calm and tranquility, essentially virtues and properties of nature which are marvelously embodied by women. Women Play a Unique and Valuable Part in Peace-Building. Women are also mobilizing the entire community for development and peace-building. They are encouraging their societies and communities to bring change through peace-making.

Women are seen as mediators at the various levels of conflict- couple, home, extended family, and the society in general. In this light, points to support women contribution to peace in Cameroon as well as a way forward will be explained in the paragraphs that follow (UNESCO Women and Peace in Africa, 2003).Widjaja (2007) indicated that women are very instrumental in keeping peace in the various ways that it is used in the society emphasizing that there are at least three dimensions of peace. First there is the dimension of physical well-being, including the absence of war, disease, or famine; Second included fair relationships between peoples and nations in this context meant that there were no economic inequalities, no injustice, and no oppression or exclusion of any other human beings. In other words, peaceful individuals do not pursue one's own interest but cares for others, regardless of who they are and finally, peace has a personal dimension that included moral integrity (Korb, 2011). Thus, the woman's role is to keep peace in all three of its dimensions.

The woman cares for the physical well-being of her household, ensuring there is food and clothes for all. The woman ensures that there are fair relationships between the members of the family, making peace when there is conflict or inequality. Finally, the woman also labors to ensure that the members of the household have moral integrity.

The issues that women are concerned about center around caring for the family and the wellbeing of those around them. Specifically, women tend to be concerned about the following issues like Caregiving to children, husbands, and others in the household; Provide the care that is necessary for healing children, husbands, or brothers are sick or injured; In education, they ensure that school fees are paid, encourage children to read their books; they give moral guidance to children to become responsible members of the society and they provide harmony When there is conflict within the family. (Korb, 2011)

The traditional African concept of peace in almost all the cultures of Cameroon, peace was equated with 'freshness,' health, well-being, harmony, calm and tranquility... When there was enough food for everyone, peace would reign in homes and families, clans and tribes. As nobody had any reason to be envious of anybody else, neighboring communities could live in peace, visit one another during the offseasons and attend weddings and funerals" (NgongoMbede, 2003, p. 28). This quote describes two of the three elements of shalom: physical well-being and relationships that are characterized by justice and equity.

More recently Korb (2011) stated that a Liberian woman gave this definition of peace that contains all three elements of peace On the personal level, peace for me is...a positive frame of mind - psychological wellbeing that allows me to be able to live from day to day as a rational, thinking, caring, responsible person. Peace on the national level for me means...that there are no insurrections, there are no military outbreaks. That law and law enforcement will be respected...Peace on the social level means that we realize, all of us, the importance of individuals as human beings, and we respect their rights to live and operate as independent human beings. That people realize our interdependence and the necessity to work together as a people in various groups but having a thread of unity running throughout" (African Women and Peace Support Group, 2004).

Men and women generally have different conflict management styles. The men may be hard in their approach and actually succeeding bu women typically adopt softer styles such as collaboration, compromise or avoiding, meanwhile men are more likely to use competing or avoiding. Collaboration produces more constructive outcomes for disputing parties and compromising behavior helps ensure harmonies, and lasting relationships. Hard bargaining tactics may be socially costly as well. As a result women's 
collaborative approach is more productive and efficient than men's hard bargaining tactics. This gender distinction has sometimes be recognized and used in conflict resolution at home and out of home (Cassandra, 2015)

\section{Actions and Activities of Women in Peace building}

Peace building activities by women include a wide range of actions and activities which are carried in the family and the community and sometimes beyond national boundary. In Cameroon, Africa and other parts of the world, women have always made a unique contribution in the peace-building process. In some areas, in peace-building and any other development, women's role therefor cannot be ignored and their contribution brings development, not only for themselves, but as well as for their entire communities, nation and world. Women can bring different issues in front of the world and can as well as their male counterparts make better decisions to solve these issues. They can better understand the issues and can truelly solve real problems and issues. (African Women and Peace Support Group, 2004)

\section{Women as peace builders in the family.}

Their contribution to peace at family level can show up in a number of ways:

\section{i-The Education of Children and care of the family} Women play a great role in educating the children, management and organization of everything connected with the home. Women train their children practical and morally, in areas such as:

$>$ Household tasks

$>$ Greeting parents in the morning,

$>$ Creating cordial relationship with neighbors

$>$ Educating the daughter who has reached the age of puberty

Well trained children grow up to build a moral society and this promotes peace. Daughters who are trained not to be lazy, dirty, and quarrelsome but well behaved, will promote less conflict in the society when they meet with people of diverse cultures.

Women also play an advisory role in relations with their husbands. They Men are always considered to be over controlling and high tempered, but women are always there to calm them down and establish peace at home. This clearly establishes the fact that women are peace makers.
Women's role is ensuring that there is food contributes to establishing peace. When there's enough food for everyone, peace reigns in homes, families, clans and tribes (Anderlini,2007)

\section{ii-Women as symbol of unity between families.}

From a structural and institutional point of view, a woman's calling in marriage creates a link binding two families, two clans, two ethnic groups or even two nationalities. The freedom of inter marriage has made the woman a symbol of unity. Also women's natural qualities of compassion, patience, discretion, gentleness, modesty and self-control reinforce their ability to unite families from different ethnic groups and maintain peace. (Anderlini, 2007 op.cit )

iii- Women as mediators in the couple, home and family

As seen in some families in most of the communities in Cameroon, women mediate between children and their fathers (parents) and between other families

menbers. Girls after being well trained by their mothers always take care of their

younger ones in ensuring that the younger ones are doing well together while

their mother is busy with family and other jobs. The older girls or sisters most of

the time are engaged in consoling, caressing and comforting as well as handling

little conflicts that take place among the children at home.( Roohia ,2012).

Okoro (2013) in his Women and Peace Initiative in Igbo Traditional Society highlighted how women can be useful peace makers through their marriage.In some communities in Cameroon, in the polygamous marriages, the first wife (called Dada Sare among Fulbe, Kindag among the Bassa, Ekomba among the Beti), is chief mediator of conflicts in the family. She is responsible for restoring peace during conflicts between husband and one of his wives. The first wife has great influence over her husband in two other ways; In the Beti tradition, being the first wife she is initiated and entrusted with all family secrets and is given official responsibility by her mother inlaw for relieving tension and ensuring a harmonious family relationships and in the Beti and Bassa Communities the first wife is sometimes invited with the men in the assemblies.( UNESCO,2003)

Examples from Somali also, show women engaged in informal peace building within their own homes. As they raise their children, the women try to teach 
tolerance and explain the futility of violence. They try everything to prevent their sons from being lured into violence. Somali women also try to get their husbands to renounce violence, threatening to leave them if they do not stop playing an active role in violence. Sisters try to convince their brothers that violence only leads to death and destruction. Likewise, in Indonesia, women are concerned that one of the worst outcomes of the ongoing conflict is that children will be destroyed by harboring feelings of revenge against the other religion's community. To curtail these feelings of revenge, women are starting at the family level where values are taught and socialized. Since the family unit is the place where either a peaceful spirit is planted or negative attitudes are developed, women are coming together to try to socialize their children towards peace (Nwoye 2004). Still about peace in the family, in Nigeria, some Muslim women share about peace with other women at naming ceremonies, weddings, and other social gatherings. If something threatens the peace of the family, then that problem becomes the woman's issue. In Jos and other areas of Nigeria, that peace is being threatened different women's groups often cry out for peace in different ways. (Agustiana \& Pakpahan)

\section{B-Womens contribution to peace building in their immediate community and nation.}

Women work at the grassroots level to organize for peace, though majority of their voices go unheard during formal processes, including: peace negotiations, disarmament, demobilization and reintegration (DDR), constitution-creation, elections, reconstruction, rehabilitation, reconciliation, and establishing a judicial system.

\section{Women do mediation in the village and Community}

In some villages, most of the time when there is a problem that threatens peace, it is usually the young girl that is push forward or the woman who makes the move for peace. Among the the different ethnic groups like in the South West Region in Cameroon the Bakossi for example, it is the paternal aunts who are responsible for reconciling the individuals involved in a conflict. In the North West Province (Nwa Subdivision), women play the role of mediators during discussions in the Lus-Mfumte. Still in this community is a very influential secret society called the Djudju whose members initially were exclusively women. The role of the Djudju women in that community initially was to maintain peace in the community but unfortunately, the men took over. Women are also known as a natural mediator. The appearance of a pregnant woman where there is violence, most of the time is like an automatic halt of violence and call for rethinking violence.(African Women and Peace Support Group, 2004 )

The pregnant woman symbolized peace among the Tikar (Kom, Menda, Bali etc) and Tchamba communities of the North-West Province. Among the Guidar, the Mazake or old women played the role of keeping watch over the community. Women are alert and react immediately to all signs of destructive conflict between members of the community. In the land of the Mungo, for example and more particularly among the Mbo any misfortune occurring in the community brought the latter to seek the mediation of the Kalbia who were married women recognized by the clanswomen as having supernatural powers(UNESCO Women and Peace 2003). Women meet with the leaders of violent groups to convince them to stop the fighting. During the Liberian war, the women used their positions as mothers and sisters to encourage the fighters to stop... (African Women and Peace Support Group, 2004 op.cit).

Women provide food and shelter for individuals who were affected by the violence.

Food and shelter is good support for those in conflict fighting for peace. Ruth Caesar said, "Even giving someone a cup of water is peace...If one sat down with a group of women to discuss their problems that is peace...If you shared your meal with another family who came into the displaced camp you were in, that's peace. If you talked to a young girl who was raped, that's peace. So we had to get involved in all those things" (African Women and Peace Support Group, 2004) 37).In this way describe women contribute to peace.

Women provide psychological healing. This is done particularly through trauma counseling. When all individuals, but particularly children, experience traumatic events especially during conflict, these young victims need support to be able to overcome the anxiety, fear, and hurt that they experienced. Women can promote psychological healing through their feminine nurturing by providing a listening ear as the traumatized share their traumatic experiences and their feelings. Women can also provide the support that is necessary for them to heal from the 
traumatic event (McGee, 2005) as also found in Okoro( 2013)

Women create awareness for the need for peace seen in shared stories of injury that provides awareness for the need for peaceful interventions.

Women shared their stories by issuing statements to key national and international leaders. Women also attended international conferences and highlighted the plight of women in Liberia.Korb (2011) indicated that Evelyn Kandakai said, "One of our strategies was awareness building. We had what we called a Peace Education Extravaganza and a Children's Peace Festival...We took a peace theatre...We were able to organize a peace education and resource center...We were one of the groups that brought about the environment for people to want to sing about peace, to talk about peace, to get involved in peace education and peacemaking" (African Women and Peace Support Group, 2004). Some women organized prayer and fasting sessions. In 1994, Liberian Women's Initiative called for all members to hold nightly prayer services in their homes at $10 \mathrm{pm}$ for the restoration of peace. These examples have been seen in Cameroon and other African countries.

\section{iV-Women provide Peace through Women's Civil} Society and close work with national government. While the virtual absence of women from the peace table is disturbing, women as individuals or part of a women's movement have played critical roles in promoting inter-ethnic dialogue, providing innovative local solutions and ensuring that there are voices of reason and even protest when heightened pressure has been necessary. From "Sierra Leone, Colombia, Nepal, Sri Lanka, Serbia, Northern Ireland, Uganda, Somalia, Cyprus ....women have made contributions that were significant and valuable in those contexts that began the transition from war to peace."

At institutional level through the influence of the government women can effectively contribute to peace building concerns. In Rwanda because of the impact of genocide on development. A Gender Desk was established in the law ministry, which resulted in reformed inheritance and marriage laws. The Justice and Reconciliation Committee incorporated women judges who were very useful for action for peace especially with concerns related to gender.( United State Dept. ,2015 )

In Kenya through the Center for Humanitarian
Dialogue: Women at the Peace Table.In response to the growing post-election violence of December 2007, the African Union (AU) deployed a Panel of Eminent African Personalities to assist with the Kenyan mediation process. This panel included a female, Grace Machel, as one of the three lead negotiators to assist in the mediation process. Much of their contribution is seen analysis from the outcome of this roundtable (United Nations Security Council, 2000).

In Ghana though at institutional level there is not much attention to gender, The National Peace Council that was established as part of the National Architecture for Peace the Mothers for Active NonViolence Local Peace Councils and Gender Training for promoting peace and stability has been very involved in the peace building process. As typical of the absence of women in politics, the DPACs currently have minimal female participation with the Northern Regional Peace Council comprised of 25 men and 3 women. With the help of UNDP, Mothers for Active Non Violence was able to train members of Peace Councils regions and advocate for the importance of more female representation on the Councils. (Korb, 2011)

In Sierra Leone and Liberia Women's organizations and human rights groups(NGO'S and civil societies have been very active in their contribution to peace The have been demanding a larger participatory role and greater accountability for the rights of women in the security sector. Women Peace and Security Network Africa) does training for accountability and Responsiveness to Gender Equality and Women's Rights to ensure more responsive and accountable delivery of security as a public good to all citizens. According to some female activist the participation of women and the integration of gender and women's rights perspectives in SSR can help to decrease gender-based violence. (Korb, 2011)

In Sudan indications for Women during conflict and peace in Sudan show some women's organizations have developed purposely to protect human rights, others to challenge women's oppression and gender inequality in post conflict situations and general reconstruction. Though women have challenges like threat of landmines, lack of agricultural inputs, and lack of legal right to land as a resource which all reduced their ability to survive; Sudanese women learned self-empowerment during war, through various activities like small income generating 
various, skills, promotion, conflict resolution, peace building initiatives and literacy campaigns(UNESCO, 2003)Women suffered during war.Man-made disasters affect both men and women, especially women and children; both are vastly marginalized in the communities that face war from social stigmatization, sociological and metal affliction from their toil as direct effect of the war, Women have also taken the initiative to form a women's caucus within the Government of National Unity. Since 2008, SuWEP has conducted capacity building trainings to educate and some other women's empowerment activities that helps women and even men to work together. (USAID, 2000).

\section{$\mathbf{v - W o m e n ~ w o r k ~ f o r ~ w a r r i n g ~ f a c t i o n s ~ t o ~ d i s a r m . ~}$}

In a number of African countries, women have done one or two things Ruth Sando Perry, a former head of the Liberian Council of State, said, "We all know that African countries do not make guns. We don't make warlike materials - they're given to us. We take over rich resources - gold, diamonds - we sell them and...instead of getting things to build our country... [we get things] to destroy our country" (African Women and Peace Support Group, 2004, p). In Somalia, women have written songs and poems that encourage peace (Mohamed, 2003). They have even organized contests calling for poems that discourage violence and promote peace. Faduma Qasim Hilwle and Zeinab Hagi Ali wrote the following song about peace on behalf of Somali women saying In the name of marriage, love and friendship women are calling for peace (Mohamed, 2003).

Apart from the above, there are many activities that women can do to foster peace in hearts, peace in society, and physical peace. Strategic peace building requires many activities from many different actors in many different ways.

\subsection{CASE STUDIES ON WOMEN} CONTRIBUTION TO PEACE IN CAMEROON Women during Conflict and Peace in Cameroon Just like the other African women, Cameroonian Women are involved in the socio economic and other activities in the country during time of peace and in the time of war. Since the country has hardly been involved in war, hardly involved in war, the women have had little to do with war, except for the Bafanfji - Balinkumbat tribal war and the case of "Takumbeng" activities in the North West Region of Cameroon, the conflict situation in Bakassi and the
Boko Haram crises in the Northern Regions of Cameroon.(Nkenzeke,2014) In Cameroon Women in Alternative Action s have women's local peace initiative. While Cameroon is not currently in a formal state of conflict the country faces a rising tide of violence, often directed at women. Cameroon women face not only "domestic violence and sexual abuse but also harmful traditional practices. These include female genital mutilation and widowhood rites that cause physical and psychological suffering. This problem is further exacerbated in rural communities where women are often restricted by cultural barriers from accessing information or voicing their concerns. To address this growing problem women's organizations are developing gender-based local peace initiatives within these rural communities. (The advocates for Human rights 2014)

In women and social groups in Cameroom, Women in Alternative Action (WAA) Cameroon recently initiated (2009) a "Queens for Peace Initiative" (QPI) with the objective of bringing together wives of traditional leaders to make their voices heard especially regarding how issues of conflict resolution and peace-building are handled in rural communities. In rural villages within North West Cameroon, 'Fons' (Male Traditional Authorities) assume full control of conflict resolution and the peaceful administration of their Fondoms. The wives of the chiefs and Fons or the 'Queens' have often been neglected from these processes and the value of their position within the community and among rural women is not fully recognized or utilized. This is true despite the contention of Justine Kwachu Kumche (Executive Director of WAA Cameroon) that the Queens "are endowed with special privileges among women in traditional settings and are the guarantors of cultures and customary practices which are buried in the psyche of the women they represent."'( Okoro, as in Roohia ,2012).)

Through the QPI program the organization is seeking to expand the voice of the Queens and by extension other women in the community. WAA has conducted several workshops to build their capacities and train them with mediation and conflict resolution skills, gender and human rights as well as legislative knowledge.

They stated "We are aiming to break the silence on discriminatory traditional practices that hamper the progress of women, enhance the integration and inclusion of rural women in the community peace 
processes and building the capacity of these women" Justine Kwachu Kumche, WAA Cameroon, 20 .To address and even overcome cultural barriers and traditional gender roles WAA undertakes creative strategies to gain access to local women. Often WAA first needed to convince the husbands (the Fons) and extend the invitation to participate through them. With assistance from the Ministry of Women's Empowerment and Family and through additional dialogue with the Fons, the organization was able to make rapid headway and received a large response from the Queens, signaling a positive start to the program (Ngongo-Mbede, 2003).

Womens participation in peace building during war has been seen in the: The Bafanji - Balikumbat Tribal War Takumbeng women activities in the North West Region of Cameroon

In the North West Region of Cameroon, there was the Bafanji and Blikumbat land dispute in 1968. In 1990, the Balikumbat leadership was changed and with the multiparty democracy attempts to define the boundaries by the Biya government, led to this tribal war between the Bafanji and the Balikumbat over the land. There were serious effects of this tribal war on the woman and the men. Here women were mostly care givers and mail runners. In the example of the Takumbeng women activities in the North West Region of Cameroon, This women Activist group took part in the Cameroon democratic crusade and its polarization in the context of multiparty politics and democratization. During this period these female riots protests and democratizations have been recorded in certain societies like in Cameroon when women in the North West Region marched naked and brought government to release Ni John Fru Ndi, leader of the Social Democratic Front party in Cameroon and other party militants who were under house arrest shortly after the release of the results of the 1993 Presidential Election.(Global conscience initiative (2011)

In the Bakassi boarder crises of Cameroon and Nigeria in the South West Region of Cameroon that lasted for more than ten years, Women in the Bakassi area and their sympathsers have been involved in local, national and international peace conferences to discuss issues in peace and security building especially those affecting the female gender. Their participation has intensified especially with news of continues threats of the Boko Haram Crises in the Far North Region of Cameroon where some women are victims of rape, kidnapping and other forms of Gender Based Violence.(Kindzeka, 2014 )

The above examples of women in peace building in other countries in Africa and Cameroon, highlights courageous and dedicated women and their organizations activities. This reports are intended to be show the vast and largely underrepresentation of of women in major political and social activism for work done by women to maintain and restore peace in Africa.

In the North West Region of Cameroon, the Political and Social Movements for Peace and Conflict Resolution by the Takembeng Women of the North West Region, Cameroon.

Photo six: Takumbeng Female Demonstrations for Peace (http://ukscnc.co.uk/2017/09/23/454/ )

Takembeng is a movement of Women in the North West Region of Cameroon. This group which is mostly made up of women in post-menopausal ages is referred to in a variety of different ways including; Takumbeng, Amazons, Les Amazons des SDF and Mami Takembeng. The socio-political mobilizations of the Takembeng women are the latest in the long history of female mobilizations in the Western Grass fields of Cameroon. Takumbeng women are "Peace Makers", they always come out with the aim to fix a particular problem that affects the community. Their movements in promoting peace in Cameroon can be divided into three major sections including; Political movements for peace, Economic activities and Moral Guardianship.

Takembeng Political Movements for Peace and Conflict Resolution role of maintaining peace in Cameroon, began in the 1950's and 60's towards the end of the colonial control. They contributed to the struggle and attainment of liberation from colonial rule and are major supporters for Democracy. Their local movements were based on protest against established policies which did not favor the smooth running of the Community. The most significant during this period is the 1958-1961 political Anlu in Kom, were women who were upset about the Agricultural policy came out to ensure that the right thing is done (Sagi-Schwartz, 2012)

This group of women in those days used their bodies to fight for freedom. To support the effectiveness of the use of their bodies, Davis (1997) states that the female body has proven to be the site of women's "subversive" practices and struggles for self- 
determination and empowerment. The display of the nakedness of the African Woman was and remains her expression of utter anger and outrage of both public injustice and private male viciousness. During the 1990 political liberalization the Takumbeng women played a crucial role in disrupting troops from elsewhere in Cameroon by stripping in front of them. Takumbeng women play a key role as mediators to fons and traditional leaders in the case of crisis and conflict. They are a source of inspiration, councellors, advisers, traditional protectors of Fons and Traditional Leaders. They support the SDF to ensure that it holds to the ideals and values of the party. In the Bambilli Village of Bamenda, the Takumbeng women who meet every "Contry Sunday" assist the Fon in the resolving conflicts of the village. This eases the work of the Fon in the community, as the dominance and power of these women is well known by all individuals. (Global conscience initiative, 2011)

These women provide Moral Guardianship for Peace by Takembeng Women. A major objective of the Takembeng Women is to ensure that the village is clean and pure. They promote cordial relationships with neighbors and uphold the command of God to "Love your neighbor as yourself". This has helped to promote peace in the North West Region and Cameroon. Throughout communities in the grass field of Cameroon, there is a longstanding practice of women gathering together as moral guardians of the community and shaming individuals who break key rules. The Takembeng women play a key role in maintaining the morality of individuals in the North West community. They often use outlandish behavior in the ostracizing of individuals in order to highlight the severity of an offense and to prevent other people from breaking the rules. This group which is made up of mostly women in post-menopausal ages gathers to shame individuals by singing songs, dressing in male attires or naked to bring out the severity of the offence. The Takumbeng women contribute much to the guidance of Traditional doctrines and cultures in the North West Region, by ensuring that it is transmitted and maintained from one generation to another. They do this by teaching the younger generation the values, ideals of traditions including; songs, traditional languages, dressing codes, traditional meals, respect of Fons and chiefdoms, respect which must be offered to different Gods, interpretation of codes and signs, just to name a few. The massive deviation from national cultures and tradition, towards western cultures has been noted as one of the major reasons for the up rise and spread of conflict globally .(Fomba, 2007)

Takumbeng Economic Activities for Peace is also important to these women. Agriculture and the establishment of "Njangi" sub groups are major efforts Takumbeng women carry out for peace and development in Cameroon. Majority of members of this group are farmers producing crops such as cocoa, cocoyam, potatoes, plantains, Rice, maize, Cassava and yams. These agricultural activities promote peace and conflict resolution by; providing food for the home and community, generating income gotten from sale of this food, and providing jobs for women who can't work in the public sphere for lack of jobs and illiteracy. Within the large group of women are sub "Njangi" groups, were money is invested, save and used after sometime. This "Njangi" groups in a long run increasing the level of circulation of physical money in the country, thereby reducing rates of inflation at a National level. (Kindzeka, 2014)

In the Bamileke's highlands of Cameroon also some individuals like twin mothers and the twin themselves are considered as agents of peace. Amongs the Bamileke, according to Ngongo-Mbede (2003), the Magne, or mothers of twins, were considered blessed by God. Their mission was, first of all, one of peace. The arrival of a Magne in a place of conflict had the immediate effect of stopping the hostile acts. Once in the midst of the confrontation, she assumed responsibility for reconciling the belligerents. She divided the 'tree of peace' into two and offered a piece to each of the protagonists as a token of reconciliation. Twins themselves were seen as tree of peace planted in the family. Her role consisted, therefore, in bringing everybody together, and considering everyone as her own child. In every situation, she had to endeavour to restore the peace required for the smooth functioning of the chiefdom. The Mafo also played the role of intermediary, in other words of mediator, between the chief and his subjects. But to gain trust and respect, the Mafo had herself to be just and to show integrity(NgongoMbede,2003)

The Cameroonian study underscored the fact that in the traditional African societies the first wife was sometimes invited to deliberate with the men in the Assemblies. As a woman in what were essentially masculine forums, one of her tasks was to 'soften' sentences considered to be too severe or which could lead to revolt or revenge. Similarly some other other 
studies reviewed drew attention to the special place in society afforded to paternal aunts in matters of crisis management and conflict resolution in traditional Africa. Thus, among the Bakossi of Cameroon, it was paternal aunts or lineage daughters (Umuada, among the Igbo of Nigeria) who were responsible for reconciling the individuals involved in a conflict. Other categories of women were given to play the same role in other societies. Hence among the Guidar of Cameroon, the Mazake or old women played the role of keeping watch over the community. They were on the alert, and reacted immediately at the least sign of destructive conflict between the members of the community. If they noticed signs of conflict or an insidious quarrel, they promptly summoned the protagonists in order to question and calm them. After this discussion, the mamas kept a watchful eye on them for an appreciable length of time, until they were satisfied that the conflict had been well and truly settled and forgotten. When they are satisfied that their advice had borne fruit, they again summoned the two protagonists and asked them to drink some bil-bil together, and then to seal their reconciliation with a kiss to celebrate peace.(Okoro,2013 op.cit)

During peace in Cameroon, there are womens groups and institutions that effectively contribute to peace building. Examples of groups and institutions include Christian Workmen's Groups like the Catholic Womens Association (CWA), Christian Women Fellowship(CWF) of the Presbyterian Church in Cameroon. The CWA and CWF through the years have spent substantial amounts of money in implementing a variety of projects geared towards reaching out to the sick, the aged, prisoners, paying school fees for orphans and other needy children, organizing workshops and seminars to educate youths on current issues such as child trafficking, HIV/AIDS awareness, the effect of the media, the environment and globalization which are all usful components for peace buildind. The CWA,CWF and other religious women's groups have constantly provided moral and financial assistance to Cameroons seminaries, clergy, religious, catechists and other members of the association(Mbuagbo,2006) as in Bisong (2018)

When it comes to women's institutions Circle of Friends of Cameroon in French ;Cercle Des Amis du Cameroun(CERAC) that promotes peace in Cameroon by contributing much in the following areas; Education of the young girl, health, Agricultural, help to vulnerable children in orphanages, fight against poverty, and assistance to victims of crisis and war. The Founding President, Mrs Biya is the leader of this group that also have some women as members from the diplomatic. Wing of the Circle. The association caries out humanitarian projects which fully intensify solidarity crusade in all the ten regions of the country as well as to implement projects of humanitarian assistance to vulnerable populations, improve living conditions, health and access to education for all kids. In the domain of Education, CERAC has been involved in the Construction and renovation of Schools in Cameroon. A good example is the case of construction of schools in Menji and Mora in 2017. The Circle of Friends in October 2017 sponsored a Computer training program of 340 individuals (255 women and 82 men) participants, at the Belo Wom (https://www.crtv.cm/2017/12/cerac-bilan-activitesperspectives-2018CERAC's solidarity train svisit all the nooks and crannies of Cameroon with messages of hope and gifts of love, but also cross the borders of Cameroon to neighboring Gabon. With exchanging views with women especially on how they can make Cameroon Africa a better place for all its citizens .Some of its projects especially those of 2015 and 2016 in the Far North, North, Centre and South West Regions, the women had charitable activities in Gabon. Later, with the donation of agricultural tools and gifts to youths in the East and South Regions. The non-profit making organization of the First Lady also rehabilitate and equip several district hospitals in the country. Amongst such hospitals is the Idenau Health Centre in Fako Division, South West Region, Bassamba Hospital in the West Region and the Faro and Deo Health Centre in the Adamawa Region. (CERAC.NEWS.ACHIVES, 2017)

Their enormous support to stability in the country has promoted peace in each of these domains. At least 35 000 persons in Cameroon have benefited from the philanthropic actions of the CERAC women

Since peace in Africa is seen equivalent to health and well-being, there is need for the introduction of welfare measures in various local African governments to benefit large families: housing, health care, means of transport and communication, loans and early child education. In this way, there is need to assess the opportunities for practices which go beyond the restitution of 'negative peace', that is, the mere absence of war, to promote 'positive peace, i.e. conditions and practices of political and social nonviolence.(Chinoa 2016) 
CHALLENGES WOMEN FACE IN THEIR CONTRIBUTION TO PEACE BUILDING

There are gender issues affecting Peace building in the different sectors of the country. Issues of violence against women and girls (particularly sexual and domestic), gender inequalities in access to and control over resources (for example, family lands, etc.)gender inequalities in power and decision-making, women's human rights (particularly reproductive rights), etc., constitute grave concerns for women, particularly rural women. Lack of participation and representation of women in the domestic and international institutions of war and peace such as parliaments, government, foreign and defense ministries, armies, peace keeping mission or UN institution constitute a serious democratic deficit. In addition, no democratic state can accept high levels of individual or collective violence against some group in that society. y. (Tirzi, 2013 op.cit .With the unanimous adoption of Resolution 1325 by the United Nations Security Council (UNESCO ) in October 2000, women's role in, and potentials for peace building have gained global, regional and national attention. Consequently, the last six years have been characterized by the identify cation of key issues on women, peace and security, and the development of interventions to address them. The challenge now is on how to ensure that these policy instruments and other recommendations are implemented, and not in a 'token' manner, but in a way that demonstrates that women are really partners in the process.

In Cameroon there are large socio-cultural, economic, political and other discrepancies between men and women that affect peace building and generally impede development. These gaps are closely related to issues of gender inequality that disadvantage women and leaves in an inferior position to men. The government of Cameroon in collaboration with other Africa states, Civil Society and some organizations like the UNO are particularly involved in programs that empower women for development, especially as the Gender equality and women's empowerment goal is central to sustainable development. Major issues include:

Women Lack political strength and political vision. Although Cameroon's constitution upholds principles of gender equality there are still some aspects of inequality in the society. Five Proportion of seats held by women in national parliament as by 2016 . The proportion of seats held by women in the national parliament of Cameroon has been a jagged progress. Indeed, if during the 1992-1996 legislature, women held $12.8 \%$ of the seats, they held $5.2 \%$ of the seats in the $1997-2001$ one, and $10.6 \%$ of the seats in the 2002-2006 one. Following the legislative elections of $2007-2012$, women represented $13.9 \%$ of the national Parliament and in 2013 there are 56 women out of the 180 seats. Overall, MDG3 remains dire in Cameroon. Ratio of girls to boys' enrollment at the primary level will likely be attained by 2015 , but it's uncertain for the secondary level and highly improbable at the tertiary level and for parity at the national Parliaments. The number of Women with ministerial post since 1995 has been on the increase for by 2010 there were 06 women out of 62 men $(9.68 \%)$ and today two.

They suffer from "political illiteracy". They lack an ideological framework that could give teeth to a strong position adopted by a collective women's. Peace building as a political activity and therefore requires political strategy for engagement (Rono, 2000).

Lack of experience, exposure and skills in negotiation, advocacy and lobbying techniques keeps them secluded from the political arena and sphere of decision-making; therefore, in many situations they are unable to participate effectively in peace building processes. Without a political platform, women are on the margins of action and lack confidence in participating in the peace building process. With the Lack of visibility their conflict-resolution activities are confined to the informal sector, very often at the periphery of official peace negotiation. In addition, even if women contribute to the promotion of peace, they are not invited to participate in formal negotiations. Lack of sustainability in political participation is a problem to women because representation does not necessarily mean meaningful and recognized participation that has an impact on substantial inputs in peace agreement. In addition, once a peace process is over, women often return to more traditional activities, losing their gains and public presence. These losses make it very difficult for women to return to the public stage later when resolution begins.

The state of women's access to and control of productive resources in Cameroon is not very good. 
Cameroon is a signatory to international policy and legal frameworks aimed at ensuring women's access to resources notably; Convention on the Elimination of All Forms of Discrimination against Women (CEDAW), The Protocol on Women's Rights, Beijing Platform for Action and the Solemn Declaration on Gender Equality in Africa (United Nations Economic Commission for Africa, 2007). In spite of these international and other national policy and legislative framework, wide gulfs still exist between women and men in access to resources leaving women with an inferior position to negotiate peace or preserve peace.Women producers in Cameroon have limited land owenership.The 1974 Land Tenure Ordinance guarantees equal access to land for all citizens, but customary laws and practices that discriminate against women's still prevail (Nforngwa, 2014), so though women constitute more than 50 percent of the Cameroonian population, they own less than $2 \%$ of the land (USAID, 2012).Women have limited control over income and access to financial services. Most financial programmes have been largely designed, with the male head of household as the intended client with the failure to see women as active, productive and engaged economic agents with their own financial needs and constraints. Limited ownership to land (the most widely used collateral in Cameroon), limit their access to credit and therefore they have insufficient cash to purchase agricultural inputs or expand their businesses. (Nforngwa, 2014 op.cit).

Inadequate access to natural and other resources can pose real problems to women's initiation and general preservation of peace. Women have limited access to education and insufficient access to extensive services (eg training ) and the use of ICT and general networking because of tradition and stereotype. This cause some of the past peace mediation methods they applied in the past without reassessing to see which of them can be modified for adoption for promoting peace among warring families, communities and nations in their country or modern Africa.In the northern regions and some rural localities of Cameroon, the male-child or son preference is a dominant cultural practicethat limits the girl child or womens education (Kassea et al, 2009).Limited education continues to widen the gender gap that is an obstacle in their participation in decision making and other round table conferences for peace talks during conflicts or post war reconstruction.
Even though it is widely accepted that the potential to advance women economically may be the most exciting transformative feature of technology (Kirrin, 2010), there is limited access to basic processing and storage of perishable goods. The female farmers in the coastal regions and Bameliki highlands involved in vegetable farming and smoking of fish often loose part of their products before they reach the local markets. They have limited access to both traditional and modern technologies and continue to use laborintensive methods, undermining their agricultural productivity. Problems with modern technologies such as internet, phones, radios etc. also deprive them of the basic benefits of technology, such as efficient household energy for cooking, heating, and lighting, as well as for home-based quality transport infrastructure useful for agricultural and industrial activities. The rural poor, majority of whom are women, have access to fuels that are inefficient in converting to energy. Thus rural women disproportionately lack access to clean, efficient, reliable, safe, and affordable energy service options. (Kirrin, 2010 op.cit),

ii-Violations of women's rights in, persistent discriminatory legislation; violence against women, including harmful traditional practices such as early and forced marriage and female genital mutilation. Despite the existence of the law prohibiting rape, there are concerns about its effectiveness in preventing sexual violence and providing protection and justice for victims. Cases of rape are still widely reported among youths and even married women. This is considered as real violence

iii-Women have limited access to education because of tradition and stereotype, Preference of males to females in education in some societies, distance location of schools especially in rural areas is a big hindrance especially to girls. Restricted resources and entitlements with respect to discriminatory customary practices which restrict women's access to school.

iv-Women Lack resources (material and financial): Inadequate financial and other resources for women is a call for cncern.Most of the time women's groups lack the means to back up their actions. In some instances, they are unable to get across to the media network to enhance their peace campaign because they do not have a budget for multi-dimensional activities. Further, they are not part of main fund raising channels and networks. They 
work on a voluntary basis at the grassroots levels, pooling their own resources together to get an office, desk, and phone line. Their limited access to public and political life and health services for Women are largely in control of the non-income economy of what Elson 19995 refers to as the care economy through bearing and raising children and providing much of the labour for household maintenance and subsistence agriculture. (Nforngwa, 2014 op.cit).

v-Cameroon's discriminatory laws towards women Cameroon's laws remain deeply discriminatory towards women and, despite observations and recommendations made by the CEDAW Committee to the Cameroon government in 2000 and 2009, no legal reforms have been undertaken to increase protection of women's human rights. Furthermore, customary law is applied alongside statutory law, creating numerous contradictions and inconsistencies. Restricted civil liberties with respect to discriminatory attitudes about the role of women in public life especially wit aspects of major decision making in traditional and other councils in the society(United State Dept. (2015) On the contribution of women's religious groups, insisted on the recognition and appreciation of fellow women who serve God in one way or the other.( United State Dept. (2015 OP Cit )

vi-Ethnic divisions \& polarization and religious differences. In some circumstances the complexity of women's ethnic and political identities made a single voice and platform difficult to attain, as noted in the Kenyan case study with women's diverging agendas mirroring the polarization in the society. Cooperation with other women - including Muslim women and those of all other religion - is absolutely necessary to bringing peace. (Coning, (2013)

Gender inequality that is evident in the persistent gender gaps mentioned above is a cost to development. The cost can be seen as the society, pays for a mothers illiteracy and lack of autonomy, poverty, more malnutrition, more illness especially venereal diseases like HIV/AIDS, and lack of good governance which are factors that generate conflict or disturb the existence of peace. Culturally, all forms of inequality and discrimination inflict an indirect cost on women men and their families leading to low productivity and efficiency as well which are serious root and immediate causes of national violence.

\section{THEWAY FORWARD TO WOMENS EFFECTIVE PARTICIPATION IN PEACE BUILDING IN CAMEROON}

The mainstream gender in peace building efforts is the way forward. It is a strategy for making the concern and experience of women as well as an integral part of design, implementation, monitoring and evaluation of policies and programmers in all political, economic and sound spheres, so that women and men benefit equally and inequality is not perpetuated.

The goal of gender mainstreaming is to achieve gender equality. Gender mainstreaming is closely linked with human rights. It is the desire to equitably distribute position, resources, interest and concern between the women and men in countries and organization, both local and international. Gender mainstreaming strives to defend particularly the right of women in the face of male chauvinism and on the altar of male biases. Many women's organization lobby at nation and international levels for handling of gender issues and particularly for the inclusion of women as active peace builders in conflict and post conflict areas. Gender mainstreaming enable policy makers to ascertain the nature of gender relations in conflict and to acknowledge the fact that men are also victims of aggression and in some cases women are also the perpetrators of aggression in conflict.(Global conscience initiative ,2011)

Mainstreaming gender is generally to create awareness that a particular gender, be it male or female should not be disfavored or alienated by the policies of both the private or government sector and international organization. It is an attempt to institutionalize gender sensitivity from the ground up. In gender mainstreaming focus is on issues such as power and resources allocation between men/women ,girls and boys, religious/cultural roles of women and men, women's participation in public and private institution boys and girls access to education, and differences in the ways women and men access economic opportunities (WIKI-GENDER, 2013)

Specific reference in gender mainstreaming if often made to the gender balance of any group in a country and how power appears to be allocated within them. Emphasis is placed on the importance of nurturing, supporting and consulting local gender expertise in the form of women's organization, such as well- 
women new conferences, roundtable and meetings. To reinforce gender mainstreaming it is prescribed that that there should be training for staff on gender issues.(World bank ,2015)Also, awareness in programmed set up is essential to ensure international and local staffs are sensitive to the gender-specific issues in conflict and post-conflict reconstructionfrom access to health, food, water and other resources to economic opportunities and female leadership at the policy/decision-making level. Policy should ensure training in skilled jobs for both men and women and programmers should encourage sexual violence counseling for men. A gender perspective in development policy whether during conflict or during peace building should embark upon:

\section{Promoting human rights}

2. Challenge women's oppression

3. Bring gender equality in Post Conflict reconstruction in every income generating activity, skills / capacity building, conflict Resolution and peace building initiative.

Because women have been traditionally assigned more to reproductive role that do not yield enough income that empowers them financially, while men have been engaged in productive roles that enable them to generate income which empowers the them in the society. This has given them an edge at the detriment of the women who are now disadvantaged. So it would be necessary that the role of gender in conflict and peace building be applied to make use the potentials of both men and women.

To achieve gender equality, women's rights and women's empowerment for the preservation of peace in Cameroon, there are three core areas: freedom from violence for women and girls; access to resources; participation in leadership and decision making. What women and girls want/need and how men and boys can help to contribute to gender equality and women's empowerment, should be clearly stated. (Okoro 2009)

1-Greater sensitization of parents against traditional customs in all the Regions of Cameroon, especially the Northern Region that predisposes the girls for marriage with its constraints, such as household chores and child bearing

2-Violence against women and girls must stop. Violence against women and girls is a manifestation of gender-based discrimination that seriously inhibits their abilities to enjoy rights and freedoms on an equal basis with men and boys. This violence, which causes great physical and psychological harm to women and girls, is a violation of their human rights, constrains their ability to fulfill their true potential and carries great economic costs for them and for society.

3-Women and girls must have equal access to resources and opportunities to reach their full potential. This must include efforts to promote decent work, reduce women's time burdens, and provide access to and control over land and productive assets, as well as to energy and water and sanitation and access to health, including sexual and reproductive health, and to skills and education at the primary, secondary and tertiary level. This protects them from the rice of violence and gives then the financial and other support to take part in decision making.

4-Women should influence decision making capacity to influence decision-making is intimately linked with their capabilities. Having a voice and participating in the processes and decisions that determine their lives is essential to women's and girls' freedoms. Therefore, the third area we propose should encompass voice, leadership and participation. It should go beyond women's participation in national parliaments to also include participation in public institutions at local and regional levels. Promoting equal decision-making in households and women's leadership in the private sector are equally important.(Nwoye, 2009)

5-Women should be provided access to justice for women with security and justice sector reforms to preventing violence against women.

6-There should be employment policies that prevent discrimination against women and enable men to take more responsibility for unpaid domestic and care work. Micro economic policies that promote inclusive and equitable growth. Infact gender should be mainstreamed, as a strategy to ensure gender perspectives are integrated in the design, implementation, and monitoring and evaluation of all policies and programmes (World Bank.,2001a)

7-For this transformative vision to become a reality, all efforts must be supported by policies that have proven most effective to achieve these outcomes, such as those outlined in the international human rights 
framework and in policy commitments such as the Beijing Platform for Action.

8-The national international community must also continue to facilitate the involvement of local women in peace negotiations. The community should also help to promote more gender awareness, and to review the content of laws that perpetuate discrimination against women, constitutional reforms, judicial reforms, election participation, as well as access to and control over economic resources, education, and training. This is because despite the ground breaking contributions made by women's groups, gender equity mechanisms created during peace negotiations still remain weak. (UNIFEM., 2004)

Peace building activities need to support women's group and local initiatives building in their own capacities, by seeing women as untapped resources and dynamic elements of post-conflict societies in Burundi, Africa, and beyond.

Therefore, there is a need to have a discussion with women's groups and movements that would convey more details on how conflict or waging conflict affects people on the ground. There is also a need to provide information about the concerns that women have, thus empowering women as major and serious actors who should be included in conflict resolution and peace building. Bop (2002).

9 Finally, there is also a need for specialized training for women in peace building. All across West Africa, it is widely acknowledged that women's participation in formal peace and security structures and processes is either nil or minimal. To cite but a few examples: at the level of the ECOWAS Peace and Security Architecture, the ECOWARN system is mainly male dominated; and at present, all the military and civilian analysts at the Observation and Monitoring Centre, which serves as the repository for information on early warning in ECOWAS, are men. Training contents must also be reviewed and tailored to address women's concerns. The development and delivery of specialized training for women should also entailed the translation into local (or first) languages of the beneficiaries to helped improve accessibility Thompson \& Eade ,2002).

\section{CONCLUSION}

Peace building efforts requires the relationship and perspectives of men and women be analysed and addressed within the context of the society in which they find themselves. The aspect of context household, organisational development, development projects and global parameters) is very crucial. This is because understanding the relationships between women and men and their access to resources, their roles and activities, and the constraints they face in their different societies is a prerequisite for tackling peace building issues; a precondition for economic growth and poverty reduction, good governance for sustainable peace. This paper argues that paying special attention to the different experiences of women and men is critical in designing successful conflict management and peace building programmes. It examines the role women play and the obstacles they continue to face in post-conflict resolution and peace building. Conflicts often force women to organize themselves to safeguard basic necessities and to carry out activities related to, for example, education and healthcare. These activities have a role to play in ensuring lasting peace and governments must ensure women are included in key peace negotiations at all levels.

\section{REFERENCES}

1. African Women and Peace Support Group. (2004). Liberian women peacemakers: Fighting for the right to be seen, heard, and counted. Trenton, NJ: Africa World Press, Inc.

2. Anderlini, S. N.Women Building Peace: What They Do, Why It Matters. Boulder, CO: Lynne Rienner, 2007

3. Changbuin M. T. (2014). The Role of Women in Conflict Solving in Cameroon: As Compared to the role of Women in African Philosophy. MF.Norwagian School of Theology Belgium

4. Agbajobi, D., 2010, 'The Role of Women in Conflict Resolution and Peace building', in eds. R. Bowd and A. B. Chikwanha, Understanding Africa's Contemporary Conflicts, African Human Security Initiative, pp. 233-254

5. Becker, H. (2003). Women, Politics and Peace in Northern Namibia. In UNESCO, Women and Peace in Africa (pp. 47-73). Paris: UNESCO Workshop

6. Bop, C. (2002). Women in conflicts, their gains and their losses. In S. Meintjes, A. Pillay, \& A. Tinshen (Eds.), The aftermath: Women in postconflict transformation (pp. 19-34). London: Zed. D'Amico, F.(1996): "Feminist Perspectives on Women Warriors." Peace Review 8, no. 3 379-84. 
7. ChinweNwoye, M. A. Role Of Women In Peace Building And Conflict Resolution In African Traditional Societies: A Selective Review Department of Philosophy \& Religious Studies | University of Nairobi philosophy.uonbi.ac.ke/node

8. Commonwealth Secretariat Information (2012)Brief "Gender Peace and Security; Commonwealth women keeping the Peace" Coning, C (2013). "Understanding Peace building as Essentially Local". Stability: International Journal of Security and Development.)

9. Fomba, c.M. (2007) researching cameroonian law. June/July 2007: Globalex. available at: http://www.nyulawglobal.org/globalex/cameroon. html

10. Frances. B., \&Kolma, W.K. (2005). Feminist theory. A reader, second edition, New York: McGraw-Hill Companies, INC.

11. IL0 (2012) Global Employment TRENDS FOR WOMEN. Information and interdisciplinary Subject.International Labour Organisation

12. Global conscience initiative (2011) Gender equality in cameroon: political participation and leadership. http://gci-cameroon.org/wpcontent/uploads/2013/01/Gender-equality-incameroon-2011.pdf

13. Kabeer N (2012) Women's Economic Empowerment and inclusion Growth: Labor Market and enterprise development. SID Working paper 2012/t.School of oriental and African Studies, UK Department for International Development and International Research Center LONDON.

14. Korb, K. A. (2011).[Role of Religion in Peace building]. Unpublished raw data.

15. Kassea R, Sakki I and Pirttilä-Backman, A (2009). Gender perceptions and schooling preferences in Cameroon. Journal of educational research in Africa. Vol. 1 (1)

16. Kirrin G, Kim B, Janna M, Payal P and Aslihan K (2010). Bridging the gender divide: How technology can advance women economically. International Center for Research on Women

17. Kavitha S. \& Ayo, C. (2010).Global Action to Prevent War:NGO Working Group on Women, Peace and Security Women's International League for Peace and Freedom
18. Kindzeka, M.e. (2014) cameroon, WHO push for end to Female circumcision. Voice of america: 17 June 2014. available at: http://www.voanews.com/content/ cameroonwho-push-for-end-to-female circumcision/1938703.html; the advocates for Human rights .

19. Lihamba, A. (2003). Women's peace building and conflict resolution skills, Morogoro region, Tanzania. In Women and peace in Africa: Case studies on traditional conflict resolution practices (pp. 111-126). Paris, France: UNESCO. Retrieved 6 August 2011 from http://unesdoc.unesco.org/images/0013/001332/13 3274e.pdf

20. Nforngwa E (2014). Giving Women Land Rights, Giving Them Solid Economic Footing. The standard tribune. Available at http://www.standard-tribune.com/?p=1823. Accessed on $19^{\text {th }}$ February 2016.

21. Mathey, M. J., Dejean, T., Deballe, M., Sopio, R., Koulaninga, A., \& Moga, J. (2003). The role played by women of the Central African Republic in the prevention and resolution of conflicts. In Women and peace in Africa: Case studies on traditional conflict resolution practices (pp. 3546). Paris, France: UNESCO. Retrieved 6 August 2011

from http://unesdoc.unesco.org/images/0013/001332/13 3274e.pdf

22. McGee, T. R. (2005). Transforming trauma: $A$ path toward wholeness. Maryknoll, NY: Orbis Books.

23. Mohamed, M. A. (2003). The role of Somali women in the search for peace. In Women and peace in Africa: Case studies on traditional conflict resolution practices (pp. 75-110). Paris, France: UNESCO. Retrieved 6 August 2011 from http://unesdoc.unesco.org/images/0013/001332/13 3274e.pdf

24. Ngongo-Mbede, Valerie,(2003). The Traditional Mediation of Conflicts by Woman in Cameroon, France: UNESCO

25. Nwoye, Agatha M.C. (2009) Role of Women in Peace building And Conflict Resolution In African Traditional Societies: A Selective Review: Nainobi Kenyatta University Press.

26. Okoro, Kingsley N. (2013)Women and Peace Initiative in Igbo Traditional Society: A Viable 
International Journal of Trend in Scientific Research and Development (IJTSRD) ISSN: 2456-6470

Option for Peace Building in Modern Africa. Humanities and Social Sciences. Vol. 1, No. 1, 2013, pp. 58-69. doi: 10.11648/j.hss.20130101.17

27. Ondoua Abena, pr., Minister of Women's empowerment and Family of the republic of cameroon, (2013) elimination and prevention of violence against women and girls: Statement at the 57 th Session of the commission on the Status of Women. new york: 5 March 2013. available at: http:/www.un.org/womenwatch/daw/csw/csw57/ generaldiscussion/memberstates/cameroon.pdf

28. Roohia S. K.(2012). "The role of Women in Mediation and Conflict Resolution: Lessons World bank (2015) Gender Data porta. available at: http://datatopics.worldbank.org/ gender/country/cameroon

29. The advocates for Human rights (2014) Written Statement to the 57 th Session of the committee on the elimination of Discrimination against Women. 24 January 2014. available http://tbinternet.ohchr.org/treaties/ceDaW/Shared percent20Documents/

cMr/int_ceDaW_nGO_cMr_16206_e.pdf

30. United State Dept. (2015) Cameroon 2014 human rights report. available at: http://www. state.gov/documents/organization/236550.pdf

31. United State Dept. (2015) cameroon 2014 human rights report. available at: http://www. state.gov/documents/organization/236550.pdf

32. UNESCO "Women and peace in Africa, Case studies on traditional conflict resolution practices", , place de Fontenoy, 75352 Paris 07 SP, France, 2003, page 27

\section{UNESCO'S}

Implementation
Mainstreaming Framowork, April 2013 htt.//www.camerounweb.com/CameroonHomePa ge/-to-consolidate-achievements-in-2017-398368

34. Ondoua, M. A. pr., Minister of Women's empowerment and Family of the republic of cameroon (2013) elimination and prevention of violence against women and girls: Statement at the 57th Session of the commission on the Status of Women. new york: 5 March 2013. page 3. available http://www.un.org/womenwatch/daw/csw/csw57/ generaldiscussion/memberstates/cameroon.pdf
35. World bank (2015) Gender Data porta. available at: http://datatopics.worldbank.org/ gender/country/cameroon

36. Okoro, Kingsley.N.(2008). "Alternative Feminism for Nigerian Women. The Gandhian Option" In African Journal of Religion. Culture and Society Vol. 2, No 1, June, 2008 (172-193)

37. Okoro, Kingsley N (2009) Women and Peace Initiative in Igbo Traditional Society: A Viable Option for Peace Building in Modern Africa. Humanities and Social Sciences. Vol. 1, No. 1, 2013, pp. 58-69. doi: 10.11648/j.hss.20130101.17

38. Suad, J ed. (2000). Gender and Citizenship in the Middle East. New York: Syracuse University Press,

39. Thompson, M. \& Eade, D (2002). Women and War: protection through empowerment in El Salvador, published in Social Development Issues 24(3),

40. UN (2013). Realizing women's rights to land and other productive resources. United Nations Organization, New York.

41. UN Women (2011). Progress of the World's Women 2011-2012: In Pursuit of Justice. United Nation Women.

42. United Nations Security Council. (2000). Resolution 1325. Retrieved 6 August 2011 from http://www.un.org/events/res_1325e.pdf

43. UNESCO "Women and peace in Africa, Case studies on traditional conflict resolution practices", 2003 , place de Fontenoy, 75352 Paris 07 SP, France.

44. United Nations (2009). World Survey on the Role of Women in Development: Women's Control over Economic Resources and Access to Financial Resources, including Microfinance. United Nations Organization, New York.

45. United Nations Economic Commission for Africa (2007). Women and Access to Land and Credit: Discussions and Key Findings of the African Gender Development Index in Selected African Countries. United Nations Economic Commission for Africa.

46. United Nations. (1996) Platform for Action and the Beijing Declaration. Fourth World Conference on Women, Beijing, China 1995 
International Journal of Trend in Scientific Research and Development (IJTSRD) ISSN: 2456-6470

47. United Nations. (2000) Security Council Resolution 1325 (2000), S/RES/1325 (2000) on Women, Peace and Security

48. United Nations Security Council. (2000). Resolution 1325. Retrieved 6 August 2011 from http://www.un.org/events/res_1325e.pdf

49. UNHCR (2013) Submission by the united nations High commissioner for refugees (unHcr) for the Office of the High commissioner for Human rights' compilation report for the 16th universal periodic review: caMerOOn. 22 april - 3 May 2013. available at: http:// www.refworld.org/pdfid/507525932.pdf

50. USAID (2012) conflict analysis Framework (caF) Version 2.0. June 2012. Washington D.c.: uSaiD, and USAID (2012) conflict assessment Framework application Guide. June 2012. Washington D.c.: uSaiD. available at: https://www.usaid.gov/what-we-do/ workingcrises-and-conflict/technical-publications

51. Widjaja, P. S. (2007). Peace. In J. Corrie (Ed.), Dictionary of mission theology: Evangelical Foundations. Nottingham: Intervarsity Press.

52. UNIFEM. (2004) A Portal on Women, Peace and Security.
Vladisavljevic, Aleksandra and Elaine Zuckerman. (2004) Structural Adjustment's Gendered Impacts: the Case of Serbia and Montenegro. Gender Action

53. USAID (2012). Strengthening Women's Property Rights in Cameroon. Available at http://www.usaidlandtenure.net/commentary/2012 /11/strengthening-womens-property-rights-incameroon. Accessed on $19^{\text {th }}$ February 2016.

54. Weber, A. (2006) Feminist Peace Theory Routledge Encyclopaedia : Autumn

55. WIKI-GENDER. 2013. GENDER EQUALITY IN CAMEROON. Available at: http://www.wikigender.org/index.php/Gender_Eq uality_in_Cameroon. Accessed: 14/05/2013

56. Women, Peace and Security Report (2002), Submitted By The UN Secretary General Pursuant To Security Council Resolution 1325 (2000)

57. World Bank. (2001a) Engendering Development: Through Gender Equality in Rights, Resources, and Voice. Policy Research Report. Oxford University Press 